


\section{Perspectives on Southern Africa}

1. The AUtobiography of an UNKnown SOUTH AFrican, by Naboth Mokgatle (1971)

2. Moderniznng Racial Domination: South Africa's Political Dynamics, by Heribert Adam (1971)

3. The Ruse of African Nationalism in South Africa: The African National Congress, 1912.1952, by Peter Walshe (1971)

4. TAIES FROM SOUTHERN AFRICA, by A. C Jordan (1973)

5. Lesotho 1970: An African Coup Under the Microscope, by B. M. Khaketla (1972)

6. TOW ARDS AN AFRICAN LUtERATURE: The Emergence of Literary Form in Xhosa. by $A$. C. Jordan (1972)

7. LAw, ORDeR, AND Liberty In SOUTH AFrica, by A. S. Mathews (1972)

8. Swaznand: The Dynamics of Political Modernization, by Christian P. Potholm (1972)

9. The SOUTH West AFrica/NAMbia Dispute: Documents and Scholarly Writings on the Controversy Between South Africa and the United Nations, by John Dugard (1973)

10. Confrontation AND Accommodation In SOUTHERN AFrica: The Limits of Independence, by Kenneth W. Grundy (1973)

11. The Rise Of Afrikanbroom: Power, Apartheid, and the Afrikaner Civil Religion, by T. Dunbar Moodie (1975)

12. Justice in SOUTH AfxucA, by Albie Sachs (1973)

13. Afrukaner Poumcs in South Africa, 1934-1948, by Newell M. Stultz (1974)

14. Crown AND Charter: The Early Years of the British South Africa Company, by John S. Galbraith (1975)

15. Poumcs of ZaMala, edited by William Tordoff (1975)

16. Corporate Poner in an African State: The Political Impact of Multinational Mining Companies in Zambia, by Richard Sklar (1975)

17. Change In Contemarorary South AFrica, edited by Leonard Thompson and Jeffrey Butler (1975)

18. The Tradmon of Resistance in Mozambique: Anti-Colonial Activity in the Ambesi Valley, 1850-1921, by Allen F. Isaacman (1976)

19. Black Potrer In SOUTH Africa: The Evolution of an ldeology, by Gail M. Gerhart (1978)

20. Black Heart: Gore-Browne and the Politics of Multiracial Zambia, by Robert I. Rotberg (1977)

21. The Black Homelands of South Africa: The Political and Economic Develop. ment of Bophuthatswana and KwaZulu, by Jeffrey Butler, Robert I. Rotberg, and John Adams (1978)

22. Aprikanfr Polmtical Thought, by Hermann Giliomee and André du Toit (1978)

23. ANGOLA UNDER the PORTUGese: The Myth and the Reality, by Gerald Bender (1977)

24. Land and Racial Domination in Rhodesia, by Robin Palmer (1977)

25. The Roots Of RURAL POVERTY: Historical Essays on the Development of Underdevelopment in Central and Southern Africa, edited by Robin Palmer and Neil Parsons (1977)

26. Mbira Music among the Shona People of Rhodesia, by Paul Berliner (1977) 
Confrontation and Accommodation in Southern Africa

PUBLISHED FOR THE CENTER ON INTERNATIONAL RACE RELATIONS, UNIVERSTTY OF DENVER 



\section{Confrontation and}

\section{Accommodation}

in Southern Africa

The Limits of Independence

\section{Kenneth W. Grundy}

UNIVERSITY OF CALIFORNIA PRESS

BERKELEY - LOS ANGELES - LONDON 
UNIVERSTY OF CALFORNIA PRESS

BERTDEY AND LOS ANGEIES, CALIFORNIA

UNIVESTTY OF CALIFORNIA PRESS, LTD.

LONDON, ENGLAND

COPYRGHT (C) 1973, BY

THE REGENTS OF THE UNIVERSITY OF CALIFORNIA

ISBN: 0-520-02271-8

IDBRARY OF CONGRESS CATALOC CARD NUMBER: $72-78950$

PRINTED IN THE UNITED STATES OF AMERICA

234567890 
To Marty,

She knows why 
